\title{
Properties of Grain, Flour and Dough in Bread Wheat Lines with Aegilops markgrafii Introgressions
}

\author{
L.V. Shchukina ${ }^{1 *}$, T.A. Pshenichnikova ${ }^{1}$, A.K. Chistyakova ${ }^{1}$, \\ E.K. KHLESTKINA ${ }^{1,2}$ and A. BÖRNER ${ }^{3}$ \\ ${ }^{1}$ Institute of Cytology and Genetics SB RAS, 630090, Novosibirsk, Russia \\ ${ }^{2}$ Novosibirsk State University, 630090, Novosibirsk, Russia \\ ${ }^{3}$ Leibniz Institute of Plant Genetics and Crop Plant Research (IPK), D-06466, Gatersleben, Germany
}

(Received 26 July 2016; Accepted 4 November 2016;

Communicated by M. Molnár-Láng)

\begin{abstract}
Various milling parameters, wet gluten content and key dough properties were analyzed for two sister lines of bread wheat with Ae. markgrafii introgressions in genetic background of cultivar Alcedo carrying a set of sub-chromosomal alien segments on chromosomes 2AS, 2BS, 3BL, 4AL and 6DL. The lines revealed higher grain vitreousness, larger particle size of flour, and higher wet gluten content in grain compared to cv. Alcedo. The flour from these lines also showed excellent water absorption and developed more resilient dough. The introgressions in the Alcedo genome caused no reduction in 1,000-grain weight. General improvement of the grain technological properties appears to be the result of introgressions into 2AS, 2BS and 3BL chromosomes. Coincidence of locations of Ae. markgrafii introgressions in chromosome with the QTLs positions for technological traits, revealed in bread wheat mapping populations, is discussed.
\end{abstract}

Keywords: bread wheat, introgressions, Aegilops markgrafii, vitreousness of grain, flour particle size, gluten content in grain, physical and mixing properties of dough

\section{Introduction}

Wild crops' relatives represent a major source of genetic variations that have potential relevance for improving disease resistance and abiotic stress tolerance. For this purpose, a number of such relatives were studied within bread wheat breeding researches (Friebe et al. 1996; Gill et al. 2011). The wheat polyploidy allows maintaining a range of entire alien chromosomes in its genome in the form of addition and substitution lines. Some of these lines have been further used for generating sets of introgression lines carrying different sub-chromosomal fragments. The manifestation of genes encoding resistance to fungal diseases can be found in some of these generated lines (Lapochkina et al. 2003; Simón et al. 2007; Leonova et al. 2008). At the same time, this genetic material is considered to be a source of traits related to drought tolerance (Reynolds et al. 2007; Placido et al. 2013).

\footnotetext{
*Corresponding author; E-mail: quality@bionet.nsc.ru
} 
Mapping populations were used for genetic analysis of wheat quantitative traits, which revealed that quantitative trait loci (QTLs) relating to different grain and flour parameters were scattered throughout different chromosomes. The lines with small introgressions in comparable genomic positions may add to allelic variability for these quantitative traits. This kind of diversity is still poorly understood and is not involved in the breeding process.

Today, only one locus $G p c-B 1$ extracted from the wild tetraploid species Triticum dicoccoides (Olmos et al. 2003) is used in wheat breeding for high protein content in grain. Its effect has been studied in different genetic backgrounds and in various environments (Kumar et al. 2011; Tabbita et al. 2013; Vishwakarma et al. 2014). Thus, the gene can be used in breeding without any negative impact on yield. Description of the effects of other exotic alleles on grain protein content and flour sedimentation volume can be found in literature (De Pace et al. 2001; Kunert et al. 2007). Derivatives of a cross between the bread wheat cultivar and tetraploid emmer wheat (Triticum dicoccum) showed high level of gluten content in grain along with a superior level of end-use quality, compared to either of the parental lines. The resulting rheological characteristics of dough and its baking qualities even exceeded cv. Saratovskaya 29 which has been considered the standard for Russian high-quality bread wheat (Budashkina et al. 1977). However, comprehensive studies of technological properties of wheat germplasm with introgressions from wild relatives are very scarce.

Previously, Schubert (cited by Weidner et al. 2004) obtained the lines of winter wheat Alcedo with introgressions from Ae. markgrafii (Greuter) Hammer. The aim of the research was to add some donor properties to bread wheat, such as resistance to powdery mildew, leaf and stem rust pathogens, as well as high content of crude protein and lysine in grains. Molecular markers revealed that the isolated 42-chromosome lines harboured the regions of introgressions in 2A, 2B, 3B, 4A and 6D chromosomes (Iqbal et al. 2007) and were resistant to leaf rust. This resistance is determined with QTL positioned in the region of introgression in $2 \mathrm{~A}$ chromosome (Iqbal et al. 2007). In this research, we describe the impact of the same introgressed segments of wheat relative Aegilops markgrafi on a range of end-use traits of Alcedo cultivar grain. The aim of this work was to demonstrate the link between the described changes in certain technological properties of flour and dough and the introgressed segments, by comparing their positions in genome to the positions of known wheat QTLs for the same traits.

\section{Material and Methods}

As a result of wide cross between bread wheat cultivar Alcedo and Ae. markgrafi, two sister introgression lines, M483/98 and M490/98, were derived as shown in Fig. 1 (according to Weidner (2004) abridged). The parent plants and the introgression lines were grown in field conditions in Gatersleben, Germany, as a single replicate in 2004 and 2008. In 2010, cv. Alcedo and the introgression lines were grown in two conditions: field and irrigated. In the latter case, daily watering was applied if there was no rainfall. The grain properties were tested in 2004, 2008 and 2010 in terms of milling quality and wet gluten 


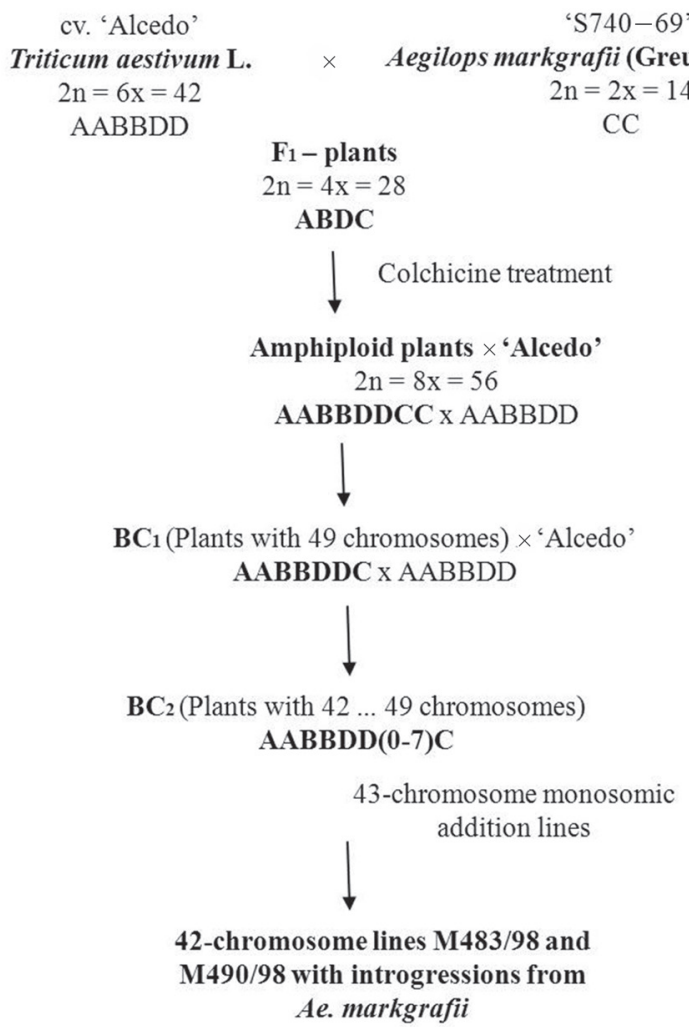

Figure 1. Crossing scheme for development of disease resistant 42-chromosome lines of bread wheat with introgressions from Ae. markgrafii

content. According to the Russian standard procedures, the milling quality tests involved 1,000-grain weight measurement, assessment of grain vitreousness, wet gluten content and mean particle size (Anonymous 1988). To determine total vitreousness, 100 grains of each sample were cut and categorized as vitreous, semi-vitreous or floury. Total vitreousness is the sum of all vitreous grains plus half of semi-vitreous grains, and is expressed as percentage. Mean particle size was determined through flour particle formation using a PSH-4 unit (Russia) which establishes the relationship between dispersed particles, layer porosity and air permeability (Shibaev et al. 1974; Pshenichnikova et al. 2010). Genotypes with the largest mean particle diameter have the highest milling performance. Wet gluten content in grain was determined manually using a micromethod based on the state standard of the Russian Federation (GOST R 54478-2011). Six grams of grain were ground for one minute in a LZM laboratory mill. The grinding fineness of wholemeal was adjusted to the size ensuring that the residual did not exceed $2 \%$ when sifting through a wire sieve no. 67 , and the pass through a silk sieve no. 38 was at least $40 \%$. Two replications of one gram of flour were each mixed with $0.65 \mathrm{ml}$ of tap water at $18-20{ }^{\circ} \mathrm{C}$ in 
porcelain bowls till homogeneity. Then, the dough ball was left at rest for 20 seconds. The gluten was washed out in tap water at $18-20{ }^{\circ} \mathrm{C}$ until starch and hulls were completely removed. The gluten content was expressed as a percentage of the wholemeal weight.

Additionally, physical and mixing properties of dough (based on Chopin alveograph and Brabender farinograph profiling) were studied using the 2010 harvest. In order to measure the flour properties such as strength $(\mathrm{W}, \mathrm{J} \times 10-4)$, tenacity $(\mathrm{P}, \mathrm{mm})$ and extensibility (L, mm), an alveograph with $50 \mathrm{~g}$ mixer was used (method ISO-5530-4-91). Mixing properties of dough such as water absorption (\%), dough development time (sec), dough stability (sec), and dough softening (farinograph units,) were determined using the farinograph (method ISO 5530-1-2013). General indicator of physical properties of dough is the farinogram area calculated using a valorimeter. The maximum farinogram area equals 100 valorimeter units (u.v.) and specifies strong wheat flour with high mixing properties. The lower valorimeter value is, the higher the dough liquefaction (Anonymous 1988).

F-criterion was used for evaluating significant differences between the mean values of Alcedo cultivar and the introgression lines (Dospekhov 1985). In order to evaluate the effects of genotype $\times$ environment on milling parameters, gluten content in grain and the alveograph parameters, two-way ANOVA was applied. Separate analyses were done for three-year and for one-year periods. The genotypes of Alcedo and the lines were considered as a fixed effect. Each year (2004, 2008 and 2010) was considered as a separate environment. One-way ANOVA was used for farinograph data analysis when the grain samples from two environments were combined. All calculations were implemented within MS Excel. Since the wild parent Ae. markgrafii was grown only for two years, its technological parameters were not included in the ANOVA analysis and were considered separately.

\section{Results}

Average values of 1,000-grain weight in the introgression lines for three years exceeded cv. Alcedo by $8 \mathrm{~g}$ (Table 1). The differences were insignificant because of high variability in the parental cultivar across the years. For example, in 2010 it was far superior, while in other years it yielded to the lines (Table S1*). On the whole, it was found that the introgressions in the Alcedo genome did not cause any reduction in the 1,000-grain weight. Average 1,000-grain weight of Ae. markgrafii equaled $1.12 \mathrm{~g}$.

The donor Ae. markgrafii showed a low level of grain vitreousness $(50.0 \%)$ and a low particle size $(14.5 \mu \mathrm{m})$. Nevertheless, the presence of its chromatin in the Alcedo genome caused more than $10.0 \%$ increase in vitreousness on average for three years. In 2010, under different watering, the line M490/98 did not differ from the initial cultivar (Table S1). Statistically significant increase in mean particle size $(\sim 2 \mu \mathrm{m}$ over the recorded value for cv. Alcedo grain) was observed for three years (Table 1).

However, wet gluten content in Ae. markgrafii grain was notably greater (42.3\%) than that in Alcedo (26.3\%, Table 1). According to the three-year data, this trait was highly expressed in the grain of introgression lines. The lines showed $7-8 \%$ preponderance over cv. Alcedo grain.

*Further details about the Electronic Supplementary Material (ESM) can be found at the end of the article. 
Table 1. Variance analysis of milling parameters and gluten content of cv. 'Alcedo' and Ae. markgrafii introgression lines M483/98 and M490/98 (harvests 2004, 2008 and 2010)

\begin{tabular}{|c|c|c|c|c|}
\hline \multirow[b]{2}{*}{ Genotypes } & \multicolumn{4}{|c|}{ Technological parameters of grain } \\
\hline & $\begin{array}{c}\text { Thousand-grain } \\
\text { weight, g }\end{array}$ & Vitreousness, \% & $\begin{array}{l}\text { Flour particles size } \\
\qquad \mu \mathrm{m}\end{array}$ & $\begin{array}{l}\text { Wet gluten content } \\
\text { in grain, } \%\end{array}$ \\
\hline Cv. 'Alcedo' & 42.0 & 70.3 & 19.3 & 26.3 \\
\hline M483/98 & 50.4 & 83.6 & 22.1 & 33.7 \\
\hline M490/98 & 49.4 & 85.6 & 20.9 & 33.9 \\
\hline $\mathrm{F}_{05}$ & \multicolumn{4}{|c|}{6.94} \\
\hline $\mathrm{F}_{\mathrm{G}}$ & $2.3(\mathrm{~ns})$ & $9.8 *$ & $11.1^{*}$ & $7.9 *$ \\
\hline $\mathrm{LSD}_{05}$ & - & 7.4 & 1.0 & 3.5 \\
\hline Genotype variance, $\%$ & - & 47.4 & 64.3 & 54.6 \\
\hline Environmental variance, $\%$ & - & 42.9 & - & - \\
\hline
\end{tabular}

$* P<0.05 ;$ ns - non-significant.

Physical properties of dough from the grain of 2010 harvest are summarized in Table 2. The flour from cv. Alcedo produced dough with a strength of $196 \mathrm{~J} \times 10^{-4}$. This value lies within mediocre range for bread wheats used for baking (Anonymous 1988; Berkutova 1991). Compared to cv. Alcedo flour, both the strength and tenacity of dough from the introgression lines were substantially greater. The lines M483/98 and M490/98 showed high flour strength (W), 367 and $299 \mathrm{~J} \times 10^{-4}$, as well as high tenacity (P), 125 and $112 \mathrm{~mm}\left(196 \mathrm{~J} \times 10^{-4}\right.$ and $75 \mathrm{~mm}$ in Alcedo, respectively). At the same time, extensibility (L) was not affected significantly by the introgression and was about the same in both cultivar and the lines (Table 2). As a result, the $\mathrm{P} / \mathrm{L}$ ratio characterizing the dough

Table 2. Alveograph derived properties of doughs made from cv. 'Alcedo' and Ae. markgrafii introgression lines M483/98 and M490/98 flours (2010 harvest)

\begin{tabular}{|c|c|c|c|c|}
\hline \multirow[b]{2}{*}{ Genotypes } & \multicolumn{4}{|c|}{ Alveograph parameters } \\
\hline & $\begin{array}{l}\text { Dough strength, } \\
\mathrm{J} \times 10^{-4}\end{array}$ & Tenacity, $\mathrm{P}, \mathrm{mm}$ & Extensibility, L, mm & $\mathrm{P} / \mathrm{L}$ \\
\hline Cv. 'Alcedo' & 196 & 75 & 65 & 1.16 \\
\hline M483/98 & 367 & 125 & 71 & 1.79 \\
\hline M490/98 & 299 & 112 & 66 & 1.81 \\
\hline $\mathrm{F}_{05}$ & \multicolumn{4}{|c|}{3.55} \\
\hline $\mathrm{F}_{\mathrm{G}}$ & $14.6^{* * *}$ & $23.2 * * *$ & $1.76(\mathrm{~ns})$ & $15.3 * * *$ \\
\hline $\mathrm{F}_{\mathrm{E}}$ & $2.43(\mathrm{~ns})$ & $29.4 * * *$ & $11.8^{* *}$ & $55.3 * * *$ \\
\hline $\mathrm{LSD}_{05}$ & 66.7 & 16.1 & - & 0.28 \\
\hline Genotype variance, $\%$ & 58.6 & 48.1 & - & 26.9 \\
\hline Environmental variance, $\%$ & 4.9 & 30.5 & 33.2 & 48.8 \\
\hline
\end{tabular}

${ }^{* *} P<0.01 ; * * * P<0.001 ;$ ns - non-significant. 
Table 3. Farinograph derived properties of doughs made from cv. 'Alcedo' and Ae. markgrafii introgression lines M483/98 and M490/98 flours (2010 harvest)

\begin{tabular}{|l|c|c|c|c|c|}
\hline \multirow{2}{*}{ Genotypes } & \multicolumn{5}{|c|}{ Farinograph parameters } \\
\cline { 2 - 6 } & $\begin{array}{c}\text { Water absorption, } \\
\%\end{array}$ & $\begin{array}{c}\text { Dough } \\
\text { development time, } \\
\text { sec }\end{array}$ & $\begin{array}{c}\text { Dough stability, } \\
\text { sec }\end{array}$ & $\begin{array}{c}\text { Dough softening, } \\
\text { u.f. }\end{array}$ & $\begin{array}{c}\text { Valorimeter } \\
\text { number }\end{array}$ \\
\hline Cv. 'Alcedo' & 59.9 & 154 & 285 & 70 & 66 \\
\hline M483/98 & 63.8 & 216 & 356 & 33 & 78 \\
\hline M490/98 & 63.0 & 190 & 325 & 42 & 73 \\
\hline $\mathrm{F}_{05}$ & $12.56 * * *$ & $3.37(\mathrm{~ns})$ & $0.72(\mathrm{~ns})$ & $3.72 *$ & $4.52^{*}$ \\
\hline $\mathrm{F}_{\mathrm{G}}$ & 1.69 & - & - & 29.3 & 8 \\
\hline $\mathrm{LSD}_{05 \mathrm{M} 483 / 98}$ & 1.78 & - & - & 31 & 8.4 \\
\hline $\mathrm{LSD}_{05 \mathrm{M} 490 / 98}$ & \multicolumn{5}{|c|}{} \\
\hline
\end{tabular}

elasticity was higher in both lines than in cv. Alcedo. The water absorption of cv. Alcedo flour was measured with the farinograph and equaled $59.9 \%$, while for M483/98 and M490/98 flour it was $63.8 \%$ and $63.0 \%$, respectively (Table 3). These differences are significant. The dough formation time and stability improved as well, although this effect was not statistically significant. The M483/98 dough liquefaction value, however, was significantly lower than that of cv. Alcedo (33 vs 70 u.f.). Therefore, its valorimeter value was significantly higher in the lines (78 vs 66 u.v.). The dough made from M490/98 line also showed better mixing properties along with longer formation time and stability during mixing than the dough made from cv. Alcedo (Table 3).

\section{Discussion}

Genotypic fingerprinting has established that both lines carry Ae. markgrafii sub-chromosomal segments on the short arms of chromosomes $2 \mathrm{~A}$ and $2 \mathrm{~B}$, and on the long arms of chromosomes 3B, 4A and 6D (Iqbal et al. 2007). The analysis of technological properties of grain and flour showed that both lines had considerably higher gluten content in grain, better water absorption, improved milling characteristics and physical properties of dough (Tables 1-3). At the same time, they retained large grain size inherent to Alcedo. This suggests commensurate potential grain productivity. Such comprehensive improvement of grain quality can be attributed to the presence of small alien fragments in the abovementioned chromosomes of cv. Alcedo.

Individual genomes of the complex bread wheat genome and the genomes of its relatives show close homoeology and collinearity. The Catalogue of Gene Symbols for Wheat (McIntosh et al. 2013) includes several homoeoallelic sets determining the variability for technological properties of flour and dough for bread wheat. Those are, in particular, the genes for grain storage proteins. It is fair to assume that there can be other homoeological sets associated with different aspects of grain quality. Some of genome regions in bread 
Table 4. Comparative genome positions of introgressions in lines M483/98 and M490/98 and QTLs for quality traits in bread wheat mapping populations

\begin{tabular}{|c|c|c|c|}
\hline \multirow{2}{*}{$\begin{array}{l}\text { Chromosome location of } \\
\text { introgressions from Ae. } \\
\text { markgrafii and markers } \\
\text { tagging the introgression } \\
\text { regions (Iqbal et al. 2007) }\end{array}$} & \multirow{2}{*}{$\begin{array}{l}\text { Improvement of } \\
\text { technological traits observed } \\
\text { in the current study in the } \\
\text { lines compared to parental } \\
\text { wheat 'Alcedo' }\end{array}$} & \multicolumn{2}{|c|}{$\begin{array}{l}\text { Similar chromosomal regions with identified QTLs } \\
\text { from the literature data }\end{array}$} \\
\hline & & QTLs, region (reference) & $\begin{array}{l}\text { The associated } \\
\text { technological trait }\end{array}$ \\
\hline $\begin{array}{c}\text { 2A; } \\
X g w m 1176-X g w m 830\end{array}$ & \multirow{3}{*}{$\begin{array}{l}\text { Gluten content in grain } \\
\text { Grain vitreousness } \\
\text { Particle size } \\
\text { Dough strength }(\mathrm{W}) \\
\text { Tenacity }(\mathrm{P}) \\
\text { P/L ratio } \\
\text { Water absorption } \\
\text { Dough softening } \\
\text { Valorimeter number }\end{array}$} & $\begin{array}{c}\text { XksuD18-Xgwm614; } \\
\text { Qpro.inra-2A (Groos et al. } \\
2003)\end{array}$ & $\begin{array}{l}\text { Protein content in } \\
\text { grain }\end{array}$ \\
\hline $\begin{array}{c}\text { 2B; } \\
\text { Xgwm148-Xgwm972 }\end{array}$ & & $\begin{array}{l}\text { Xbarc55-wmc175; QWgc.caas- } \\
\text { 2B (Li et al. 2009) }\end{array}$ & $\begin{array}{l}\text { Wet gluten content } \\
\text { in grain }\end{array}$ \\
\hline $\begin{array}{c}\text { 3B; } \\
\text { Xgwm } 1005\end{array}$ & & $\begin{array}{c}\text { Xgwm72-Xwmc612; QFyeld. } \\
\text { wak-3B, QMscor.wak-3B } \\
\text { (Carter et al. 2012) }\end{array}$ & $\begin{array}{l}\text { Flour yield, milling } \\
\text { score }\end{array}$ \\
\hline
\end{tabular}

wheat have already been identified as the carriers of QTLs associated with the quality traits studied in this work. Relevant literature data are summarized in Table 4. The introgressed segment most likely responsible for the increased wet gluten content in M483/98 and M490/98 is the one on chromosome 2AS defined by the microsatellite loci Xgwm1176 and Xgwm830. This chromosomal region harbours QPro.inra-2A, a QTL associated with grain protein content in Renan $\times$ Récital mapping population (Groos et al. 2003). This parameter well correlates with wet gluten content (Kozmina 1969; Kulkarni et al. 1987; Zhang et al. 2008). Recently, it has been shown that the introgression from Triticum timopheevii in the same region of the short arm of 2 A chromosome significantly improves this trait (Pshenichnikova et al. 2015). The introgressed segment from Ae. markgrafii defined by the microsatellite loci Xgwm 148, Xgwm374 and Xgwm972 in 2B chromosome may be the donor of high gluten content in grain as well. In the mapping population Neixiang $188 \times$ Yanzhan 1, Li et al. (2009) revealed the associated QTL in the region of the molecular marker Xbarc55 which is positioned only in $2.4 \mathrm{cM}$ from Xgwm374 (GRAINGENES Database, http://wheat.pw.usda.gov).

Small introgression in 3BL chromosome was only indicated by one microsatellite marker Xgwm 1005 (Iqbal et al. 2007) and was positioned between the markers Xgwm108 and $X g w m 112$. It may include the genetic factor determining variability for two tightly correlating milling traits: vitreousness and flour particle size (Dunduk and Ermakova 1978). Carter et al. (2012) discovered a comparable region in 3BL chromosome between the markers $X g w m 72$ and $X w m c 612$, where several loci associated with milling parameters in the mapping population of soft-grain cultivars Louise $\times$ Penawawa were co-localized. Pshenichnikova et al. (2008) managed to show by QTL mapping in ITMI population that the region of chromosome arm 3AL centered on the microsatellite locus Xmwg 30 is associated with vitreousness and particle size. Ermakova et al. (2008) demonstrated that most $(85 \%)$ members of a cultivar panel producing flour with a large particle size carry a particular Xgwm0003 allele (mapping to chromosome arm 3DL), and the same allele was 
present in 54\% of the cultivars producing highly vitreous grain. The above chromosomal regions on chromosomes $3 \mathrm{~A}, 3 \mathrm{~B}$ and $3 \mathrm{D}$ are homoeologous with one another, as shown by marker analysis (Röder et al. 1998). Possibly, this region of chromosomes of the third homoeological group in bread wheat is associated with variability for vitreousness and flour particle size. It should be added that in chromosome $3 \mathrm{~A}$, in the region of marker Xbcd115 at a distance of $2 \mathrm{cM}$ from $X m w g 30$, a QTL associated with milling flour yield in the mapping population Schomburgk $\times$ Yarralinka was found (Parker et al. 1999). Two additional small introgressions in 4AL and 6DL chromosomes were found in both lines; they were indicated with microsatellite markers Xgwm160, Xgwm732 and Xgwm1003, respectively (Iqbal et al. 2007). No loci for quality parameters have been mapped to these chromosomal regions in bread wheat.

Possible presence of orthologous loci relating to the quality traits in Ae. markgrafii agrees with N. Vavilov's law of homologous series. The results obtained are the basis for further generating of lines with single introgressions as well as mapping populations, to confirm the role of each specific introgression site in quality traits formation.

The lines showed significantly higher farinograph water absorption compared to the initial cultivar. Most likely, this is the pleiotropic effect of genetically determined increase of gluten content in grain, vitreousness and flour particle size. These parameters are known to positively correlate with water absorbing capacity (Kulkarni et al. 1987; Pshenichnikova et al. 2008). The improvement of physical properties of flour and dough in the lines compared to Alcedo might also be a consequence of the mentioned traits improvement. Now the both sister lines can be classified as strong wheats, the improvers of weak flour. Nevertheless, the line M490/98 had worse physical and mixing properties of dough than the line M483/98. It may suggest that this line carries a somewhat different set and/ or size of introgressions from Ae. markgrafii, than described by Iqbal et al. (2007).

The 2AS segment introgressed in M483/98 and M490/98 also harbours QLr.ipk-2A responsible for resistance to leaf rust (Iqbal et al. 2007; Weidner et al. 2008). Thus, both wet gluten content and leaf rust resistance can be obtained concomitantly. There is a widespread opinion stating negative correlation between protein (gluten) content in wheat grain and yield (and grain size). However, a set of genotypes were obtained, which carried the $G p c-B$ lgene increasing protein content in grain without reducing yield (Kumar et al. 2011; Tabbita et al. 2013; Eagles et al. 2014). In further research (Groos et al. 2003), the revealed locus QPro.inra- $2 A$ for grain protein content variability was not associated with yield components either. Furthermore, Khlestkina et al. (2009) did not find any negative correlation between grain protein content (conferred by the QGps.ipk-7B locus on chromosome 7BS) and grain size. In this study, such negative correlation was not observed as well.

\section{Acknowledgements}

The work was supported by ICG project (No 0324-2016-0001). The authors declare no conflict of interest. 


\section{References}

Anonymous 1988. Method of state variety testing of crops. Gosagroprom. Moscow, Russia. (in Russian)

Berkutova, N.S. 1991. The methods of evaluation and formation of grain quality. Rosagropromizdat. Moscow, Russia. pp. 10-22. (in Russian)

Budashkina, E.B., Dunduk, I.G., Ermakova, M.F. 1977. Hybrid 21 - a new form of strong spring wheat. Izvestiya SO AN SSSR (ser. biol. nauk) 1:80-83 (in Russian).

Carter, E.H., Garland-Campbell, K., Morris, C.F., Kidwell, K.K. 2012. Chromosomes 3B and 4D are associated with several milling and baking quality traits in a soft white spring wheat (Triticum aestivum L.) population. Theor. Appl. Genet. 124:1079-1096.

De Pace, C., Snidaro, D., Ciaffi, M., Vittori, D., Ciofo, A., Cenci, A., Tanzarella, O.A., Qualset, C.O., ScarasciaMugnozza, G.T. 2001. Introgression of Dasypyrum villosum chromatin into common wheat improves grain protein quality. Euphytica 117:67-75.

Dospekhov, B.A. 1985. The technique of field experiment (with the basic statistical processing of experimental results). Agropromizdat. Moscow, Russia. (in Russian)

Dunduk, I.G., Ermakova, M.F. 1978. Grain hardness trait as indicator of wheat quality. Sibirskiy Vestnik selskokhozyaistvennoi nauki 1:15-19. (in Russian)

Eagles, H.A., McLean, R.B., Eastwood, R.F., Appelbee, M.-J., Cane, K., Martin, P.J., Wallwork, H. 2014. Highyielding lines of wheat carrying $G p c-B 1$ adapted to Mediterranean-type environments of the south and west of Australia. Crop Pasture Sci. 65:854-861.

Ermakova, M.F., Chistyakova, A.K., Shchukina, L.V., Morozova, E.V., Khlestkina, E.K., Pshenichnikova T.A. 2008. Diversity of Siberian bread wheat cultivars on grain quality in dependence of the breeding period. EWAC Newsletter, Proc. 14th Intern. EWAC Conference, 6-10 May 2007. Istanbul, Turkey. pp. 174-176.

Friebe, B., Jang, J., Raupp, W.J., McIntosh, R.A., Gill, B.S. 1996. Characterization of wheat-alien translocations conferring resistance to diseases and pests: current status. Euphytica 91:59-87.

Gill, B.S., Friebe, B.R., White, F. 2011. Alien introgressions represent a rich source of genes for crop improvement. Proc. Natl Acad. Sci. USA 108:7657-7658.

Groos, C., Robert, N., Bervas, E., Charmet, G. 2003. Genetic analysis of grain protein-content, grain yield and thousand-kernel weight in bread wheat. Theor. Appl. Genet. 106:1032-1040.

Iqbal, N., Eticha, F., Khlestkina, E.K., Weidner, A., Röder, M.S., Börner, A. 2007. The use of simple sequence repeat (SSR) markers to identify and map alien segments carrying genes for effective resistance to leaf rust in bread wheat. Plant Genetic Resources: Characterization Utilization 5:100-103.

Khlestkina, E.K., Giura, A., Röder, M.S., Börner, A. 2009. A new gene controlling the flowering response to photoperiod in wheat. Euphytica 165:579-585.

Kozmina, N.P. 1969. Grain. Moscow, Russia. (in Russian)

Kulkarni, R.G., Ponte, J.G., Kulp, K. 1987. Significance of gluten content as index of flour quality. Cereal Chem. 64:1-3.

Kumar, J., Jaiswal, V., Kumar, A., Kumar, N., Mir, R.R., Kumar, S., Dhariwal, R., Tyagi, S., Khandelwal, M., Prabhu, K.V., Prasad, R., Balyan, H.S., Gupta, P.K. 2011. Introgression of a major gene for high grain protein content in some Indian bread wheat cultivars. Field Crops Res. 123:226-233.

Kunert, A., Naz, A.A., Dedeck, O., Pillen, K., Leon, J. 2007. AB-QTL analysis in winter wheat: I. Synthetic hexaploid wheat (T. turgidum ssp. dicoccoides $\times$ T. tauschii) as a source of favourable alleles for milling and baking quality traits. Theor. Appl. Genet. 115:683-695.

Lapochkina, I.F., Iordanskaya, I.V., Yatchevskaya, G.L., Zemchuzhina, A.I., Kovalenko, D.E., Solomatin, D.A., Kolomiets, T.M. 2003. Identification of alien genetic material and genes of resistance to leaf rust in wheat (Triticum aestivum L.) stocks. Proc. 10th Intern. Wheat Genet. Symp. Paestum, Italy. pp. 1190-1192.

Leonova, I.N., Röder, M.S., Kalinina, N.P., Budashkina, E.B. 2008. Genetic analysis and localization of loci controlling leaf rust resistance of Triticum aestivum $\times$ Triticum timopheevii introgression lines. Russian J. of Genet. 44:1431-1437.

Li, Y., Song, Y., Zhou, R., Branlard, G., Jia, J. 2009. Detection of QTLs for bread-making quality in wheat using a recombinant inbred line population. Plant Breeding 128:235-243. 
McIntosh, R.A., Yamazaki, Y., Dubcovsky, J., Roger, J., Morris, C., Appels, R., Xia, X.C., 2013. Catalogue of gene symbols for wheat. 12th Int. Wheat Genet. Symp. Yokohama, Japan. http://wheat.pw.usda.gov/GG2/ Triticum/wgc/2013/GeneCatalogueIntroduction.pdf

Olmos, S., Distelfeld, A., Chicaiza, O., Schlatter, A.R., Fahima, T., Echenique, V., Dubcovsky, J. 2003. Precise mapping of a locus affecting grain protein content in durum wheat. Theor. Appl. Genet. 107:1243-1251.

Parker, G.D., Chalmers, K.J., Rathjen, A.J., Langridge, P. 1999. Mapping loci associated with milling yield in wheat (Triticum aestivum L.). Mol. Breeding 5:561-568.

Placido, D.F., Campbell, M.T., Folsom, J.J., Cui, X., Kruger, G.R., Baenziger, P.S., Walia, H. 2013. Introgression of novel traits from a wild wheat relative improves drought adaptation in wheat. Plant Physiol. 161:1806-1819.

Pshenichnikova, T.A., Ermakova, M.F., Chistyakova, A.K., Shchukina, L.V., Berezovskaya, E.V., Lohwasser, U., Röder, M.S., Börner, A. 2008. Mapping of the quantitative trait loci (QTL) associated with grain quality characteristics of the bread wheat grown under different environmental conditions. Russian J. of Genetics 44:74-84.

Pshenichnikova, T.A., Simonov, A.V., Ermakova, M.F., Chistyakova, A.K., Shchukina, L.V., Morozova, E.V. 2010. The effect on grain endosperm structure of an introgression from Aegilops speltoides Tausch into chromosome 5A of bread wheat. Euphitica 175:315-322.

Pshenichnikova, T.A., Simonov, A.V., Shchukina, L.V., Morozova, E.V., Chistyakova, A.K., Börner, A. 2015. Enlargement of the genetic diversity for grain quality in bread wheat through alien introgression. (Chapter 32). In: Ogihara, Y., Takumi, S., Handa, H. (eds), Advances in Wheat Genetics: From Genome to Field. Proceedings of the 12th International Wheat Genetics Symposium. Springer Japan. Tokyo, Japan. pp. 287-292.

Reynolds, M., Dreccer, F., Trethowan, R. 2007. Drought-adaptive traits derived from wheat wild relatives and landraces. J. Exp. Bot. 58:177-186.

Röder, M.S., Korzun, V., Wendehake, K., Plaschke, J., Tixier, M., Leroy, P., Ganal, M.W. 1998. A microsatellite map of wheat. Genetics 149:2007-2023.

Shibaev, P.N., Guzev, I.S., Samsonov, M.M. 1974. Vitreousness and structural-mechanical properties of wheat grain. Selektsia i semenovodstvo 3:22-26.

Simón, M.R., Ayala, F.M., Cordo, C.A., Röder, M.S., Börner, A. 2007. The use of wheat/goatgrass introgression lines for the detection of gene(s) determining resistance to Septoria tritici blotch (Micosphaerella graminicola). Euphytica 154:249-254.

Tabbita, F., Lewis, S., Vouilloz, J.P., Ortega, M.A., Kade, M., Abbate, P.E., Barneix, A.J. 2013. Effects of the $G p c-B 1$ locus on high grain protein content introgressed into Argentinean wheat germplasm. Plant Breeding 132:48-52.

Vishwakarma, M.K., Mishra, V.K., Gupta, P.K., Yadav, P.S., Kumar, H., Joshi, A.K. 2014. Introgression of the high grain protein gene $G p c-B 1$ in an elite wheat variety of Indo-Gangetic Plains through marker assisted backcross breeding. Curr. Plant Biol. 1:60-67.

Weidner, A. 2004. Selection and characterization of wheat - Ae. markgrafii introgression lines resistant to leaf rust. PhD Thesis. Martin-Luther-University. Halle Wittenberg, Halle (Saale), Germany.

Weidner, A., Schubert, V., Eticha, F., Iqbal, N., Khlestkina, E.K., Röder, M.S., Börner, A. 2008. Symptom expression and chromosomal location of leaf rust resistance from Aegilops markgrafii introgressed into hexaploid wheat background. Proc. 14th Intern. EWAC Conf., 6-10 May 2007. Istanbul, Turkey. EWAC Newsletter, pp. 79-82.

Weidner, A., Röder, M.S., Börner, A. 2012. Mapping wheat powdery mildew resistance derived from Aegilops markgrafii. Plant Genetic Resources: Characterization and Utilization 10:137-140.

Zhang, W., Chao, S., Manthey, F., Chicaiza, O., Brevis, J.C., Echenique, V., Dubcovsky, J. 2008. QTL analysis of pasta quality using a composite microsatellite and SNP map of durum wheat. Theor. Appl. Genet. 117:1361-1377. 


\section{Electronic Supplementary Material (ESM)}

Electronic Supplementary Material (ESM) associated with this article can be found at the website of CRC at http://www.akademiai.com/content/120427/

Electronic Supplementary Table S1. Thousand-grain weight, grain vitreousness, grain wet gluten content and mean flour particle size of cv. 'Alcedo' and Ae. markgrafii introgression lines M483/98 and M490/98 (2010 harvest) 